\title{
The Effect of Image Message Perception on Cigarette Background and The Intention to Stop Smoking Teenagers
}

\author{
Sarah Fadhila Siregar ${ }^{1}$, Putra Apriadi Siregar ${ }^{2}$, Apriliani ${ }^{3}$, Rani Elviyanti Siregar ${ }^{4}$, and \\ Nur Fadhilah Hasanah ${ }^{5}$ \\ 1,2,3 Universitas Islam Negeri Sumatera Utara, Medan, Indonesia
}

\begin{abstract}
Smoking behavior in Indonesia is still high. Health warning for room cigarette smoke is $50 \%$ of the surface of cigarette packs, but Indonesia is still a country with cigarette smoke in ASEAN at $40 \%$. This study aimed to determine the effect of cigarette packaged image messages on adolescent smoking intentions in Medan. This study used a cross-sectional method. The number of samples in this study was 68 teenagers in Medan City. This study uses a questionnaire as a primary data aid. Bivariate analysis using the chi-square test. The results showed that there were $52.9 \%$ respondents aged $20-21$ years and had a general department of $52.9 \%$, as many as $52.9 \%$ of respondents in semester 4 were $55.9 \%$. The majority of respondents aged 20-21 years without consuming 1-5 cigarettes/day were $55.6 \%$. Responding to fear of cigarette packaged picture messages and having the intention of smoking as much as $14.7 \%$. Respondents were not afraid of the cigarette packaged picture messages and had no intention of quitting smoking as much as $17.6 \%$. It can be detrimental to respondents that with the perception of fear, the message of cigarette packs of images has a risk of 1,885 times the intention to quit smoking than respondents who do not have the perception of fear of the cigarette pack image message. It is hoped that the government will expand the picture message on cigarette packets to increase the desire to quit smoking and reduce the number of smokers in Indonesia.
\end{abstract}

Keywords: Cigarette picture message; smoking behavior; intention to quit smoking; adolescents

KEYWORDS

Cigarette

picture

message;

smoking

behavior;

intention to quit

smoking;

adolescents

\section{INTRODUCTION}

Tobacco use is the leading global preventable cause of death. WHO (World Health Organization) attributes nearly 6 million deaths per year to tobacco worldwide. This figure is expected to increase to more than 8 million deaths by 2030. Smoking is the main form of tobacco use, and globally there is an increase in cigarette consumption, especially in developing countries. It is estimated that the number of smokers worldwide reaches 1.3 billion people (World Health Organization Regional Office for South-East Asia, 2015). 
Tobacco use, especially smoking, is one of the causes of death and illness in chronic diseases such as heart disease, chronic lung disease, cancer, diabetes and stroke. Based on Basic Health Research Data in 2013, there has been an increase in premature deaths due to tobacco from 190,260 deaths (2010) to 240,618 deaths (2013), as well as an increase in people suffering from tobacco consumption from 384,058 people (2010) to 962,403 people (2013) (Riskesdas, 2013).

Today the problem of smoking is still national and even international. The handling must be done massively because it involves various aspects of problems in life.

Based on data from the WHO (World Health Organization) in 2015, it was stated that cigarette consumption of the population in Asia and Australia was 57\%, cigarette consumption among residents of Eastern Europe and the Part of the Soviet Union was $14 \%$, cigarette consumption in the population of America was $12 \%$, consumption cigarettes among the population in Western Europe amounted to $9 \%$, cigarette consumption in the population in the Middle East and Africa was 8\%. 10\% of the population in the ASEAN region are active smokers in the world. The death rate (CFR) due to smoking is $20 \%$ in the world (World Health Organization Regional Office for SouthEast Asia, 2015).

The incessant advertising, promotion and sponsorship of cigarettes impact the increasing prevalence of smoking in adolescents. The number of cigarette users in Indonesia is increasing. Indonesia is the fourth largest country globally after China, Russia and America in terms of consuming cigarettes. The 2018 Basic Health Research Data shows that people in Indonesia claim to have smoking behaviour every day as much as $24.3 \%$ and have occasional smoking behaviour as much as 4.6\%. The 2018 Basic Health Research data results showed $52.1 \%$ of the first-time smoking behaviour in adolescents aged 15-19 years, adolescents aged 20-24 years stated that they first smoked as much as 14.8\% (Tim Riskesdas 2018, 2019).

The 2018 Basic Health Research Data shows that North Sumatra Province, which has a smoking behaviour every day, is $22.38 \%$ and those who have smoking behaviour sometimes are $4.78 \%$. For the first time in adolescents at the age of $15-19$ years, smoking behaviour was $48.81 \%$, adolescents aged 20-24 years stated that they first smoked as much as $29.56 \%$.

Medan City, which has smoking behaviour every day, is $18.16 \%$ and which has smoking behaviour sometimes is $6.69 \%$. The first smoking behaviour of adolescents at the age of 15-19 years was $43.84 \%$, adolescents aged 20-24 years stated that they first smoked as much as $31.10 \%$ (Tim Riskesdas 2018, 2019).

In 2008 WHO formulated a practical control strategy known as the MPOWER. MPOWER stands for six effective efforts to reduce cigarette consumption. The picture message on 
cigarette packs is included in the Warning point (community awareness of the dangers of tobacco) to reduce smoking prevalence in Indonesia (Dewi, 2015).

In Indonesia, tobacco control policies have been carried out, including Government Regulation No. 109 of 2012 concerning the Safety of Materials Containing Addictive Tobacco Products for Health. The Government Regulation was strengthened by the issuance of the Minister of Health Regulation No. 28 of 2013, which was later updated to Minister of Health Regulation No. 56 of 2017 concerning Amendments to the regulation of the minister of health number 28 of 2013 concerning the Inclusion of Health Warnings and Health Information on Tobacco Product Packaging in the Form of Pictures and Texts. The two policies are mandated by Law No. 36 of 2009 on health.

The Minister of Health explains the inclusion of health warnings and health information on tobacco product packaging and contains the requirements for the inclusion of the intended health warnings and information, including the type and colour of the image, the method of writing, and the location of the placement. Picture messages on cigarette packs are $40 \%$ of the surface of cigarette packs (Redaksi Sehat Negeriku, 2013). When the three ASEAN countries are moving towards the adoption of standard plain cigarette packs, the change in warning images on cigarette packs in Indonesia is still unclear. Moreover, enlarge the image to 75 per cent from now, which is only 40 per cent.

The results of the Tobacco Control Support Center (TCSC) and IAKMI (2015) survey analysis which states that images of oral cancer, lung cancer and bronchitis, and pictures of throat cancer are the images most feared by smokers and the most effective way to convey information about the dangers of smoking (TCSC, 2013).

Hamdan's research (2015) stated that a p-value (sig. 2-tailed) was obtained in hypothesis testing, which was greater than the value of $=0.05$. This means that $\mathrm{H} 0$ is rejected and $\mathrm{H} 1$ is accepted, meaning that there is an effect of warning about the dangers of smoking on the intention (intention) to stop smoking.

The results of Santoso's research (2016) stated that the regression test results showed that the pictorial warning variable had a positive effect on the intention to quit smoking with a coefficient value of 0.344 . This indicates that if the pictorial warning variable increases, the choice to stop smoking will also increase.

The results of Krisnasari's research (2017) state that there is a significant relationship between pictorial warnings and the intention (intention) to quit smoking ( $p$-value $<0.05$ ), the perception of a good visual sign increases the intention (intention) to quit smoking by 5.9 times.

The results of Yuliati's (2015) study state that visualizing health hazards on cigarette packs is enough to bring about changes in attitudes for smokers, heavy smokers to reduce 
their smoking habits, and want to quit smoking The use of visual warning labels on cigarette packets has high success in providing effective education on the dangers of smoking. Visualization of health hazards on cigarette packs has succeeded in convincing a positive influence on a smoker's motivation to quit smoking (Yuliati et al., 2015).

Permatasari \& Rosita's research (2013) stated that the picture message on cigarette packs affected student attitudes towards the intention to stop smoking in undergraduate students in Malang City. The attitude variable has a Beta coefficient of 0.277 , so it has a significant effect on quitting smoking. In this study, it is known that the R Square value is 45.3\% (Permatasari \& Rosita, 2013).

Trisnowati's research (2018) shows that the five PKB are considered very helpfully in reminding smokers of the dangers of smoking to motivate teenagers to stop smoking or reduce smoking habits. The number of teenage boys who smoked was more than $37.2 \%$, while the number of adolescent girls who smoked was $6.9 \%$. There is a significant relationship between adolescents' perceptions of the five PKB with childish smoking behaviour with $\mathrm{P}$ values $(0.039 ; 0.001 ; 0.025 ; 0.022 ; 0.027)$. Respondents who have a positive perception of $\mathrm{PKB}$ tend to reduce cigarette consumption; on the contrary, respondents who have a negative perception of PKB tend to continue to smoke (Trisnowati et al., 2018).

Tuter's research (2017) states that the t value is 2.720 , while the $t$ table value is 1.995 . This is because the t count of 2.720 is greater than 1.995 , it can be said that there is a significant effect of health image messages on cigarette packs on smoking behaviour in students (Tuter et al., 2017).

Based on the description and information above, the researcher is interested in conducting research entitled The Effect of Image Message Perception on Cigarette Packs and the Intention of Quitting Adolescent Smoking in Medan City. This study aimed to determine the effect of picture messages on cigarette packs to quit adolescents in Medan.

\section{METHODOLODY}

This study used a quantitative analytic approach with a cross-sectional design (crosssectional) using primary data. This study aims to determine cigarette packaged image messages on adolescent smoking cessation intentions in Medan City. This research was conducted in Medan City. During January - June 2019. The population in this study were adolescents aged 18-23 years. The sample of this study was 68 teenagers. The research instrument used a questionnaire containing the characteristics (age, department, semester), the number of cigarette consumption per day, the perception of picture messages on cigarette packs and the intention to stop smoking. Data analysis used cross- 
tabulation descriptive analysis than presented in a frequency distribution table using SPSS 22.

\section{RESULT AND DISCUSSION}

\section{Univariate Analysis}

Table 1. Frequency Distribution of Respondent Characteristics

\begin{tabular}{lcc}
\hline \multicolumn{1}{c}{ Characteristics } & F & \% \\
\hline Age Group & & \\
\hline $18-19$ years & 27 & $39,7 \%$ \\
\hline $20-21$ years & 36 & $52,9 \%$ \\
\hline $22-23$ years & 5 & $7,4 \%$ \\
\hline Department & & \\
\hline General & 36 & $52,9 \%$ \\
\hline Religion & 32 & $47,1 \%$ \\
\hline Semester & & \\
\hline Semester II & 22 & $32,4 \%$ \\
\hline Semester IV & 38 & $55,9 \%$ \\
\hline Semester VI & 7 & $10,3 \%$ \\
\hline Semester VIII & 1 & $1,5 \%$ \\
\hline
\end{tabular}

Based on Table 1, it is known that the majority of respondents in the 20-21 years age group were 36 (52.9\%). Respondents with general majors were 36 (52.9\%), with the majority in the 4 th semester as many as 38 (55.9\%).

\section{Bivariate Analysis}

Table 2. The proportion of the Characteristics of the Age Group of Adolescents with the number of teenagers' cigarette consumption per day

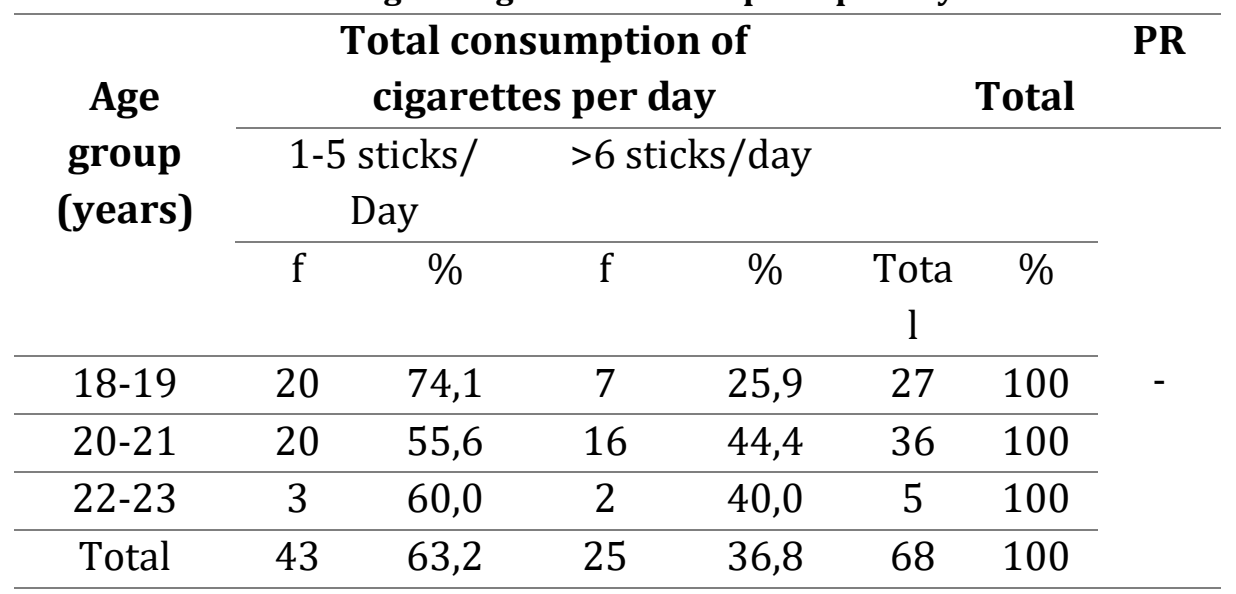

The results of this study stated that of the 27 respondents in the 18-19 age group, 20 (74.1\%) had 1-5 cigarettes/day and 7 (25.9\%) cigarettes per day. Of the 36 respondents 
in the 20-21 years age group, 20 (55.6\%) and $>6$ cigarettes/day consumed 1-5 cigarettes (44.4\%). Of the 5 respondents in the $22-23$ age group, $3(60 \%)$ and $>6$ cigarettes/day consumed 1-5 cigarettes (40\%).

The results of this study showed that the majority of respondents had a total of 20 (55.6\%) teenagers' cigarette consumption (55.6\%) in the 20-21 years age group. The results of this study are in line with Aldani (2016), which states that as many as 94 teenage smokers, 47 (50\%) consume 1-5 cigarettes every day. It can be concluded that adolescents are smokers in the light category because smoking is just the beginning (Aldani, 2016).

Factors that influence adolescent smoking behaviour are internal and external factors. The transitional period experienced by adolescents, such as the rapid physical and psychosocial changes at puberty, is an internal factor. This condition often becomes a conflict within the teenager and also with the surrounding environment. External factors also affect adolescents' ability to adapt to the family and school environment (Fitrianda, 2013).

The results of this study found that the majority of respondents have smoking behaviour in the age group of 20-21. All over the world, smokers start smoking when they enter their teens. This data is relevant to Basic Health Research data (2018) which shows that the highest teenage smokers are in the 20-24 years age group.

The results of this study stated that the majority of respondents were in general majors as many as 36 (52.9\%). Respondents who are in the general department have a different understanding of their religion with respondents who are in the religious department. Religion is an organized belief or belief and worship that is practised as a spiritual expression. A person's perception or perspective can also be influenced by religion (Potter \& Perry, 2005).

The results of this study stated that the majority of respondents were in the fourth semester as many as 38 (55.9\%)-respondents who are in the fourth semester who belong to the category of adolescents at the final level. Adolescence is a time when imitating and trying things he has never done, such as smoking behaviour. This research is in line with Yuliarti (2013) which states that out of 60 adolescents based on the characteristics of the semester group, and it is known that the majority of respondents, namely the fourth semester as much as $46.7 \%$ with the majority at the age of 21 years as much as 35\% (Yuliarti, 2013). 
Table 3. The proportion of Perception of Picture Messages on Cigarette Packs with the Intention of Quit Smoking by Adolescents in Medan City

\begin{tabular}{|c|c|c|c|c|c|c|c|}
\hline \multirow{4}{*}{$\begin{array}{c}\text { Perception of } \\
\text { Cigarette Pack } \\
\text { Picture } \\
\text { Message }\end{array}$} & \multicolumn{4}{|c|}{ Intention to Quit Smoking } & & & \multirow[t]{4}{*}{ PR } \\
\hline & \multicolumn{2}{|c|}{ Yes } & \multicolumn{2}{|c|}{ No } & \multicolumn{2}{|c|}{ Total } & \\
\hline & $\mathrm{f}$ & $\%$ & $\mathrm{f}$ & $\%$ & Tota & $\%$ & \\
\hline & & & & & 1 & & \\
\hline Afraid & 10 & 14,7 & 27 & 39,7 & 37 & 100 & 1,885 \\
\hline Not Afraid & 19 & 27,3 & 12 & 17,6 & 31 & 100 & \\
\hline Total & 29 & 42,6 & 39 & 57,4 & 68 & 100 & \\
\hline
\end{tabular}

The results of this study stated that based on the cross-tabulation results obtained from 37 respondents who had a perception of fear of the cigarette pack image message with the intention to stop smoking as many as 10 (14.7\%) and did not have the intention to stop smoking as many as 27 (39.7\%). In this study, it is known that respondents who have a perception of fear of cigarette packs of images and have no intention of quitting smoking are higher by 27 (39.7\%). This research is in line with Hutabarat (2019), which states that $59 \%$ of adolescents have positive perceptions and have no intention of quitting smoking after seeing picture messages on cigarette packets. This is because they assume that as long as they have smoking behaviour, they do not experience the disease as illustrated on the cigarette pack package. Thus, adolescents who have positive perceptions about picture messages on cigarette packs, but cannot influence the change in adolescent smoking behaviour. Around them, there were many smokers, but not one person was affected by the disease as in the picture on the cigarette pack package, so they were of the view that whether or not there was a health hazard image on the cigarette pack package had no effect on their health or the same (Hutabarat et al., 2019).

Adolescents find it difficult to end smoking behaviour due to dependence on chemical substances and social habit factors. Efforts to end smoking behaviour will mean nothing if followed by a strong will. Meanwhile, the desire to quit smoking is still influenced by social support factors to end smoking behaviour. If the social environment does not want to and is not interested in smoking, then adolescents will be able to actualize their intention not to smoke more and more, and vice versa. Thus, the steps that should be taken for smokers who want to end their smoking habit are to have the intention to quit smoking. Thus, the intention to quit smoking can predict the chance of success in quitting smoking (Rosita et al., 2012).

The results of this study indicate that respondents with a perception of fear of cigarette packaged picture messages have a risk of 1.885 times the intention to quit smoking compared to respondents who do not have a perception of fear of cigarette packaged picture messages. This study is in line with Adiayatama (2016) which states that the contribution of text and images of the dangers of smoking on cigarette packs has a relatively slight effect on changes in smoker behaviour by $25 \%$. The psychology of adolescents to illustrate the most fearful images based on their experiences that they 
have known about the impact of smoking will affect adolescent perceptions (Adiayatama et al., 2016).

In this study, it is known that respondents who have the perception of not being afraid of the cigarette pack image message but have the intention to stop smoking are higher by $19(27.3 \%)$. The results of this study are in line with Hutabarat (2019) that active smokers are accustomed to seeing picture messages on each cigarette pack so that it does not cause the impact of fear, at first adolescents, are afraid of the display of the hazardous cigarette advertisement image on the cigarette pack. Images that are seen continuously, in fact, do not have such an impact for active smokers, which makes adolescents immune or casual to this information and no longer cares about the warning images of the dangers of cigarettes on the cigarette packs.

\section{CONCLUSION}

In this study, it is concluded that the majority of respondents have smoking behavior in the age group of 20-21 years with the number of cigarette consumption 1-5 cigarettes/day and the perception of fear in the cigarette pack image message has a risk of 1.885 times the intention to quit smoking compared to respondents who have no perception. Afraid of the cigarette pack picture message. The success of adolescents in trying to quit smoking is determined by the extent to which they intend to quit smoking. Thus, it is hoped that the government will conduct socialization and coordinate with all relevant agencies and routine monitoring regarding the implementation of health warnings and health information on cigarette packaging, hoping that BPOM will not find any more violations by the cigarette industry. And also, the hope that the government can expand the picture message on cigarette packs to increase the success of teenagers to stop smoking and reduce the number of smokers in Indonesia.

\section{REFERENCES}

Adiayatama, I., Suryatna, U., \& Kusumadinata, A. A. (2016). Pengaruh Pesan Gambar Bahaya Merokok Terhadap Perubahan Perilaku Perokok. Jurnal Komunikato, 2(1), 67-96. http://dx.doi.org/10.30997/jk.v2i1.210

Aldani, N. A., Usman, S., \& Tahlil. T. (2016). Pengaruh peringatan visual pada bungkus rokok terhadap perilaku merokok pada siswa SMA. Jurnal Ilmu Keperawatan, 392, $8(1), 20-26$.

Dewi, R. N. (2015). Penerimaan Perokok Dan Mantan Perokok Terhadap Perubahan Label Peringatan Bahaya Rokok Yang Lama Ke Label Peringatan Bahaya Rokok Yang Baru (Publication No. 33667) [Master's thesis, Universitas Airlangga]. 
Perpustakaan Universitas Airlangga.

Fitrianda, M. I. (2013). Pengaruh Penggunaan Media Boneka Tangan Terhadap Kemampuan Menyimak Anak Kelompok B Di RA Nurul Hidayah Kecamatan Rambipuji Jember Tahun Pelajaran 2017/2018 [Unpublished Undergraduate Thesis]. Universitas Jember.

Hamdan, S. R. (2015). Pengaruh Peringatan Bahaya Rokok Bergambar Pada Intensi Berhenti Merokok. MIMBAR, Jurnal Sosial Dan Pembangunan, 31(1), 241-250. https://doi.org/10.29313/mimbar.v31i1.1323

Hutabarat, E. N. N., Rochadi, R. K., \& Aulia, D. (2019). Pengaruh Karakteristik Dan Persepsi Individu Tentang Peringatan Bahaya Merokok Pada Bungkus Rokok Terhadap Perubahan Sikap Perokok Aktif Di Lingkungan Xxvii Kelurahan Pekan Labuhan Kecamatan Medan Labuhan. Jurnal Muara Sains, Teknologi, Kedokteran Dan Ilmu Kesehatan, 3(1), 9-20. https://doi.org/10.24912/jmstkik.v3i1.1539

Krisnasari, S., Dewi, F. S. T., \& Wahab, A. (2017). Peringatan kemasan rokok bergambar dan intensi berhenti merokok di Kabupaten Sleman. Berita Kedokteran Masyarakat, 33(4), 181-186. https://doi.org/10.22146/bkm.16999

Permatasari, L. P. \& Rosita, N. F. (2013). Pengaruh Sikap, Norma Subjektif, Dan Kontrol Perilaku Terhadap Intensi Berhenti Merokok Sebagai Dampak Peraturan Gambar Peringatan Pada Mahasiswa Strata Satu di Kota Malang. Jurnal Ilmiah Mahasiswa Fakultas Ekonomi dan Bisnis Universitas Brawijaya, 3(2), .

Redaksi Sehat Negeriku. (2013, June 1). Permenkes 28/2013: Pencantuman Peringatan dan Informasi Kesehatan pada Kemasan Rokok. Sehat Negeriku. https://sehatnegeriku.kemkes.go.id/baca/rilis-

media/20130601/198034/permenkes-282013-pencantuman-peringatan-daninformasi-kesehatan-pada-kemasan-rokok/

Rosita, R., Suswardany, D. L., \& Abidin, Z. (2012). Penentu Keberhasilan Berhenti Merokok Pada Mahasiswa. KEMAS: Jurnal Kesehatan Masyarakat, 8(1), 1-9. https://doi.org/10.15294/kemas.v8i1.2252

Santoso, F. M. (2016). Pengaruh Pesan Pictorial Warning Kemasan Rokok pada Niat Berhenti Merokok: Uji Evoked Fear sebagai Variabel Pemediasi (Publication No. 11817) [Bachelor's thesis, Universitas Atma Jaya Yogyakarta]. UAJY's Library.

TCSC. (2013, March 21). Indonesia Tobacco Atlas Edisi 2013. Tobacco Control Support Center - IkatanAhli Kesehatan Masyarakat Indonesia. http://tcscindonesia.org/wp-content/uploads/2014/02/Atlas.pdf 
Tim Riskesdas 2018. (2019). Laporan Provinsi Sumatera Utara RISKESDAS 2018. Lembaga Penerbit Badan Litbang Kesehatan.

Trisnowati, H., Nabut, O. E., \& Marlinawati, U. (2018). Persepsi terhadap Peringatan Kesehatan Bergambar pada Bungkus Rokok dan Perilaku Merokok Remaja di Yogyakarta. Jurnal Kedokteran Dan Kesehatan, 14(2), 10-20. https://doi.org/10.24853/jkk.14.2.10-20

Tuter, R. M., Warouw, D. M. D., \& Kalesaran, E. R. (2017). PENGARUH GAMBAR KESEHATAN PADA KEMASAN ROKOK TERHADAP PERILAKU MEROKOK (Studi Kasus Pada Mahasiswa Fakultas Ilmu Sosial Dan Politik Universitas Sam Ratulangi). ACTA DIURNA KOMUNIKASI, 6(4), 1-11.

World Health Organization Regional Office for South-East Asia. (2015). Global Youth Tobacco Survey (GYTS): Indonesia report 2014. SEARO Publications.

Yuliati, R. (2015). Dampak Visualisasi Ancaman Kesehatan pada Bungkus Rokok Terhadap Perubahan Sikap Perokok Di Wilayah Samarinda Ulu. eJournal Ilmu Komunikasi Universitas Mulawarman, 3(2), 81-91. 